\title{
The Street Art/Graffiti of Youth: Questioning the Normalizing Influence of Tradition
}

\author{
Pat Rafferty \\ Professor \\ Department of Elementary Education \\ University of Alberta
}

The paper presented in this special issue of Phenomenology + Pedagogy stands to represent my abiding interest in understanding the significance of visual representation as a search for meaning. To make meaning visually representational is taken as an attempt to objectify what we feel and know. If we accept that visual representation is a human search for meaning, then we might ask what it is that prompts us to socially reify certain forms of expression while dismissing others.

Assisted by a Canada Council grant I set out to study street art, a form of popular culture that has frequently been ignored in our haste to reify other more institutionalized forms of visual representation. The results of this study of street art have implications bearing on the often tenuous position paid to other more evasive forms of visual representation. Why does the art of children, the street artist, and other culturally specific groups stand outside mainstream art?

Working in the Faculty of Education at the University of Alberta, I have been fortunate to have the opportunity to share the results of this study with a diverse range of affable groups including the Canadian Broadcasting Corporation, ITV National Journal, the Visual Anthropological Association, The American Popular Culture Association's 20th Annual meeting, and the North Pacific Popular Culture Association.

Street art/graffiti, a form of popular culture, has attempted in recent years to reappropriate "the rite of passage" of artistic expression away from what is believed to be the dominant culture of a prescribed mainstream art. What are the social processes by which active relations of domination and subordination are played out in the drama of sanctioning what gets legitimized as art? I will focus on street art/graffiti as a new domain of consciousness challenging conventional ways of legitimizing what is presented and accepted as art. Rather than resign themselves to the taken-for-granted disjuncture between popular culture and institutionalized art as inevitable grounds for social rejection, several street artists/graffitists view the tension as a healthy means of transcendence into conditions encouraging innovation. In this article I explore the 

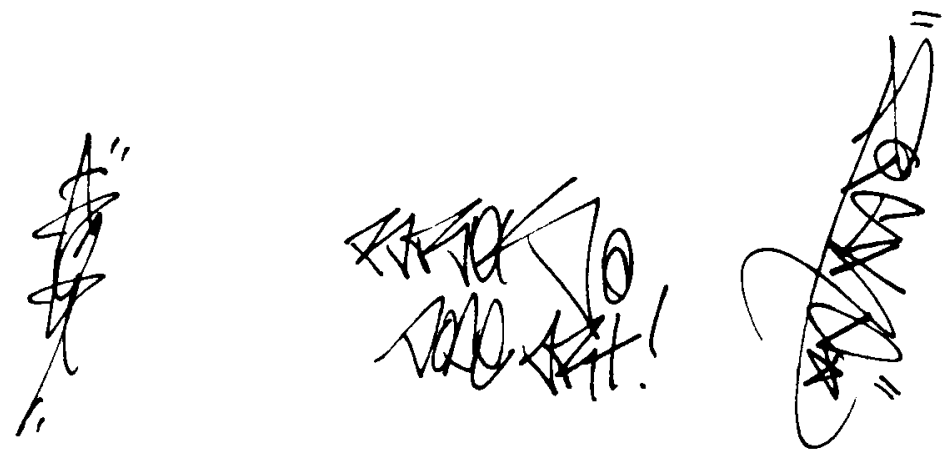

\section{Tag graffiti.}

character of change mechanisms that find the street artist/graffitist choosing to be simultaneously inside the social mainstream and outside of institutionalized art structures.

Street art/graffiti found in Vancouver, British Columbia reveals several different subcultures with stylistic differences linked by significant crosscurrents and forming a pervasive counterculture movement. Its overall popularity gained momentum in the late 1970 s with a series of provocative announcements such as: "Free Love: Can you afford it?" "Despise authority: It despises you!" and "Post-Autonomic Cow: Precooked." Away from the easel and the pedestal and dressed as advertising text the work was challenging. Acker (1984) says, "Language is that which depends on other language. It's necessarily reactive. An isolated word has no meaning. Art whether or not it uplifts the spirit, is necessarily dependent on contexts such as socio-economic ones" $(1984, \mathrm{p}$. 35 ). The artist as social and political satirist manipulates mainstream conventions to advantage. The artist does not include himself or herself in the frame of modernity. Rather, in a kind of parody the artist gestures toward it, and in affirming this course experiences the freedom of his or her choices.

Concurrent with the first kind of street art/graffiti, a proliferation of a second kind appeared in Vancouver and was labeled Tag Graffiti by its makers. Originating in New York, it was interpreted as an outright assault on urban architecture. The identity of an individual or gang was established by "getting up" a signature in as many places as possible around town without getting caught.

A third kind of graffiti grew out of a sustained interest in Tag Graffiti. As signatures were drawn increasingly larger and as artists became more adept at using spray paint, the emergence of diagonals, dots, arrows, spirals, and highlighting techniques gave character to scaled-up letters 


\section{University of Alberta}

creating an overall razzle-dazzle of vibrant colors appropriately labeled Wild Style.

\section{Social and Political Satire Graffiti}

During the early 1970 s a loosely woven network of aspiring artists and writers made a break into the public venue by raising graffiti to a new level of significance. Whatever their differences, by choosing graffiti as a means for expression and circumcumventing the whole question of what is and is not art, these young initiates acquired direct access to the public. As 12 Midnite explains, "Graffiti is the best way to advertise an idea." In reclaiming the responsibility for making art as a lifestyle, these artists were assuming control over the means of distribution, thus reaffirming the particularity of their own personal vision of art as an integral part of everyday life. Feeling betrayed by institutional constraints that limit access to conventional channels of communication and distribution, they turned to the streets for access without censorship. By nature they were too energized to get stuck on reduplicating the achievements methods and icons of past artists.

Lincoln Clarkes, Richard Hambleton, Ed Varney, and Michael de Courcey were among a growing number of artists who came to be known as "illegal street artists." They seemed undaunted by the consequences of being perceived as deviant and they moved in and out of the urban alleyways, leaving behind a wake of paper paste-ups, freehand drawings, photos, and stenciled images. "Part of the reason why I started doing stencils was because of the neatness of the idea. It's so neat. Its concise. Its quick. You can't miss making your point. Its there! It's discreet," says 12 Midnite.

Skillfully engineered, this kind of graffiti had the authority of a corporate logo repeated in rapid-fire succession all over town. Stencils, freehand painting, photos, and paper paste-ups were used to create multiple images, giving the appearance of small advertisements. In an ironical twist they set in use the very tactics of a system they felt had been ignoring them. Mimicking symbolic techniques of the advertising trade-its style, strategy, and form - their work was as purposeful as that of any advertising executive charged with accelerating an image flow. They delivered contradictory messages by embedding their message in imagery mimicking form of mass media production, thus luring the spectator into reaction. Leaving the message insinuated rather than obvious, they hoped to lure the passive urban eye into a state of cultural shock. A public constantly bombarded by advertisements for Trident Mints, Wonder Bra, Pampers, and Ex-Lax is going to wonder what the inducement is in a message that reads "1984: Coming Soon."

The street artists familiarized themselves with pathways through the city that bore little resemblance to the experiences of the banker, lawyer, or accountant. The Neo-graffitist was the manifestation of Toffler's 
(1970) modular person surviving in a time of accelerated change by meeting invention with invention.

Michael de Courcy actually mapped some of these pathways in his Urban Wilderness project. He provided a map with three walking tours through the city complete with stenciled messages on the sidewalks pointing to "mountain views" in between buildings, "urban wildlife," and so on. A more recent project involved putting up posters of composite images of urban walls and billboards with the message "poster" printed across it in several of the different languages spoken in Vancouver.

Richard Hambleton had left Vancouver for New York in 1980 leaving behind several hundred large-as-life diazo prints of himself plastered all over the city. These gaping, life-size figures earned him the label pop-expressionist, a parody on modernity's generic expressionism.

Away from Vancouver, American artists Keith Haring, Jean-Michel Basquiat, Kenny Scharf, and "out-of-towner" Hambleton achieved superstardom in the New York art circuit. Hambleton was invited, along with a number of other street artists, to show in commercial galleries in New York. Gallery owners observed the animated interaction between the public and these brash young upstarts and recognized a chance to revive the public's interest in the mainstream art circuit.

The edition of Hambleton paste-ups that had become a hot item in New York succumbed to the Vancouver rain, leaving an aftermath of ghostlike images about town-an unpleasant reminder to local artists like Clarkes that even the climate can be dispassionate about new ideas.

Lincoln Clarkes came to Vancouver from Toronto in 1979 with a portfolio of photographic scenarios, collages, paintings, and sculpture intended to attract public attention by defacing what we take for granted:

Nobody knew it was me in the beginning, because I wasn't signing my work. It wasn't for about a year afterwards that I started signing my paintings. And when I started doing my stuff I did so much of it that everybody started talking about all this stuff that was creeping up around town. I can remember going to Hamburger Mary's on Denman Street, with Ann, and we'd just spent a few hours zipping around town spray painting and we went to this hamburger place and ran into some friends, a group of four artists. Bob Alexander is a 45-year-old sort of older artist that's been around for years and is pretty well known in the art circles and he was talking about these spray paintings that were creeping up. I was talking to them and said, "Yeah, I seen those things all over town, they look quite neat" and all those people started talking. They didn't know that it was me and I didn't tell them and I just thought, "Oh my god they're talking about me, and didn't even know it." That was the first time. It was a real turn-on! 


\section{University of Alberta}

By the mid-1980s, Clarkes had settled in as a patriarchal figurehead and his work shifted away from graffiti to commercial photography. He continued to be a mentor to young street artists/graffiti seeking him out.

Several of the social and political satire graffitists gambled on making the leap from fame as a street artist/graffitist to the mainstream art circuit on their own terms. The prestigious Heiffel Gallery in Vancouver held a one-person show of Clarkes' work but the work did not sell. Not surprisingly, the transformative work required to meet gallery demands proved to be overly constraining for a kind of art that received its essential vitality on the street. The acceptance of the artist's work as art lies not only in the work but in the ability of others to accept work marginalized by the preferred aesthetic. Critics of graffiti have tended to ignore differences among graffiti writers and their creations choosing instead to respond to the work in total as that of either artists or uncontrollable predators."

If the dominant culture has a tendency to react by situating the street artist/graffitist as deviant, then why do street artists/graffitists persist? Big Dada, a middle-aged working man with a family, prompts the question of what motivates a person to do graffiti art:

There are a number of things. On a personal level, it is fun. It's a little bit dangerous because you can get caught. That flirting with danger is fun. It brings you immediately into the present where your major concern is how you are going to accomplish this without getting caught. It forces you to become hyper-aware of your surroundings. I've always been a little naughty. It perpetuates this image of me. And I feel that I am doing a service, I am getting a cosmic message out without the overlay of the ego ... I started doing graffiti in the early seventies. For $\$ 1.99$ you could get a few words cut on stencil paper at Hewitts and I'd walk around with a can of paint and do what I called Commando Art. Most graffiti is very concise. Often it is very directed politically but there is no way of finding out who is doing it. That's why I say that it rises out of the cultural consciousness, it's like the walls are expressing themselves. It isn't selling anything except a world view. Anonymity is important because it keeps you from getting caught and it keeps the messages universal, sourceless. It draws its power from its aggressiveness and its accessibility.

Graduating from the Emily Carr College of Art and Design, 12 Midnite spent some time exploring urban centers in California where he undertook to express the violence, alienation, suspicion and survival instincts through his art.

I moved down to California hoping to pull it off that way. And then I thought, well, this is scary. This is bad news. I can't walk down the street without the police talking to me or someone taking a picture of me or someone asking me to buy drugs or someone asking to sleep with me-to pay me, to buy me, or to have them buy me. I realized that, "God, this isn't the place to be" and so I came back. And then all of a sudden I got on to the statue of Liberty. 


\section{0th Anniversary of the Faculty of Education}

I said "That's it! That's our symbol!" Because it's been so bastardized and everything. What a great idea, freedom for everybody but it didn't work for me down there. It wasn't freedom for me down there. And it came down to the fact that liberty is enforced by power and by guns.

I am trying to save the world. By going out there and saving Canada at least. I am trying to open people's eyes by using the best method available to me. It is not just what I think is going on. It is going on. Its the annexation of Canada into the United States and the disintegration of our country. I don't agree with violence, I don't agree with drugs or religion and I deal with those things through my art.

Thomas Anfield, alias Pablo Fiasco, strives to show his work at commercial galleries. He is a graduate of the New York Academy of Art and approaches his neo-expressionistic portrayals of the human condition in a very disciplined manner, all the while manipulating his career in order to learn more about established ways of determining success.

When I started I wanted the public art to be decorative and lighter than what I was doing at home on canvas. I started to do them on little pieces of canvas and I put them up around town but they got ripped off so fast that I started to paint them directly on the wall ... You know my reason was that I was an artist and my work deserved to be seen. So, I took my art to what seemed to be the logical place to take your art at the time which was directly to the public, especially in Vancouver. Art galleries don't have much life here. Its a very small percentage of people who will venture to the art galleries. Which is like any city I guess.

When people introduced me as Pablo Fiasco it rubbed me the wrong way. I just hated it! Well, it is a double-edged sword, because I never tried to get rid of it because I was quite aware of the value it had. I don't know if you saw that I was in Vancouver Magazine this month. There is a perfect example. There's no way that they would have said "Thomas Anfield, he's not a bad painter. Let's put him in this Magazine." Forget it! It's useless. But, Pablo Fiasco, to them-the media-is a very interesting thing. So, as I said, it is a double-edged sword. Here you are in the art world trying to get respect for what you do, to make a decent living to pay the rent, you've got to say to someone "Pay a thousand dollars for this canvas." So you don't want to be associated with something less serious like the kid on the street with the spray can. So, it has been very useful. There's no way that I would have been in that magazine if it weren't for Pablo Fiasco.

Toby, a young graffiti artist, achieved a bit of stardom when he was fined $\$ 200$ for painting a series of figures on the sidewalks of Stanley Park. A developer interested in Toby's ambition to take his art to the people offered him space on a hoarding on Robson Street and help in auctioning off the work at the end of the project. None of the works sold. Toby was disillusioned by the outcome and left for Toronto.

When I go down and paint on the sea walls, I feel that I am doing cave art and I almost feel myself back in the caves painting on walls. There, I'm painting Michaelangelos on canvas and I can sense what it must have been 


\section{University of Alberta}

like to paint all those frescoes. You have a link with these artists so that you become a part of that level of art, and you can go right back to the days of the Egyptians and you can feel that art. And you're a part of thatyou've never really died. You know what I'm saying? And you've never really been born, you've just always sort of been here. This life that you're living now is a physical manifestation of that.

I was painting apartment suites and I had started to earn enough money that I had a single little apartment and a studio down in Gastown. So, I could go work in my studio, I could do bigger paintings, and I had my living quarters separate from my studio which was so nice because I could have a nice, neat, clean apartment to live in, and a place to work. It was wonderful! Then, I lost my job, so I went on UIC. I ended up living in my studio and I did that for awhile. Then I moved out of my studio and into this place. I got another job working in a massage parlor. I was like a desk clerk in a massage parlor. That was part time, and that allowed me enough time to work, go to work, earn enough money to pay my rent and so on, and do all the things I wanted to do. And that's when I started doing street art, I had to do something, because if I kept going the way I was going, it was going to be rotten-you know, work at a job then go home and work, and then you don't have time to get to your work outside your apartment. So I figured, I've got to do something now. If the galleries won't take my work and I can't get anywhere, then I'm just going to give it to them free. And the best thing I can do is just take it on the sidewalk.

\section{Wild Style and Tag Graffiti}

In the early 1980s the then forward-looking social and political graffiti of Vancouver was rivalled by a new kind of work on the streets called Wild Style. This unique form had grown out of the Hip-hop movement which

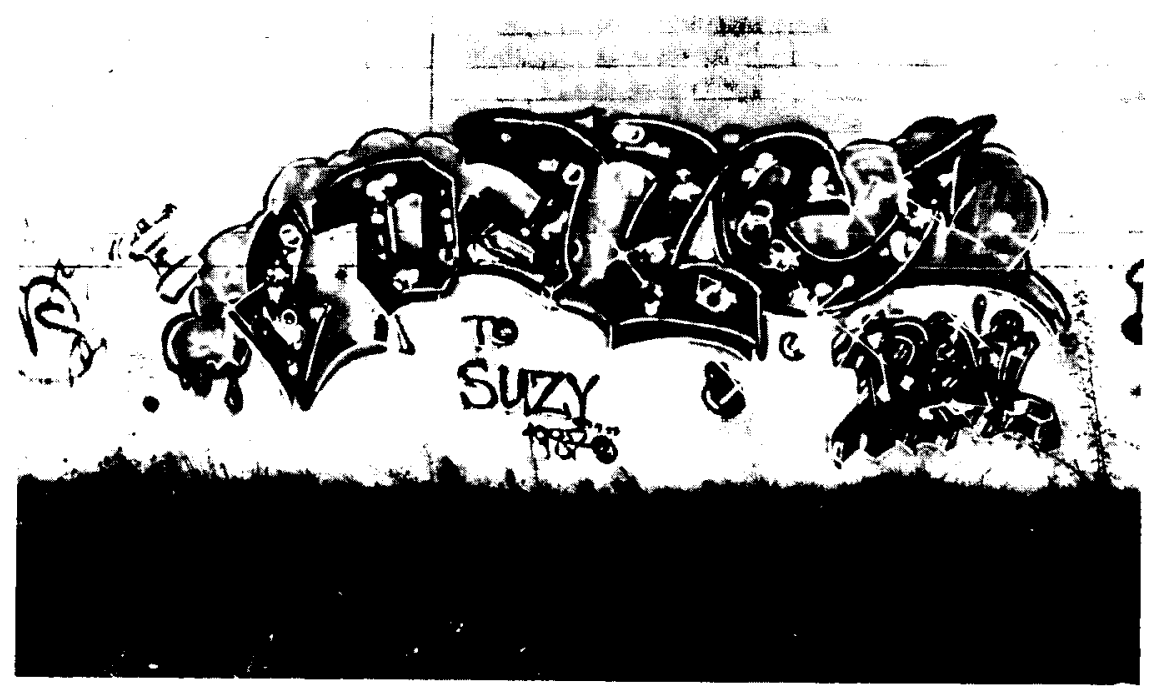

Wild style graffiti. 
originated in New York in the early 1970s. The movement is an authentic indigenous street culture inspired by the youth of New York who use the city as a backdrop for its manifold forms-break dancing, rapping, scratching, and graffiti. It emerged as an alternative to gang warfare-a level of violence among youth that gripped that urban community between 1968 and 1973. Wild Style began as Tag Graffiti-the signing of an alias on the city walls.

The sole motivation of the tag graffitist seems to be focused on a hit-andrun tactic for marking territory. The idea is to take an alias-Risk-e Cazal, Bozo, Jimbo, Misty, Style (2), Zephr, Rip-and with it achieve a style which, when repeated, communicates one's presence and everywhereness without fear of retaliation. For the pedestrian who has no access to the game or its players the marks mean only the defacement of property or an act of empty conformity. Of the several different kinds of graffiti, people have the least regard for tagging. The police, other civic officials, downtown merchants, and more importantly other graffitists lament the growing interest in tagging.

Wild Style evolved out of the practice of tagging. The label tag refers to a group of highly stylized letters in a format that makes the end result appear much like a commercial logo when indeed it is publicizing the assumed name of a graffitist. Wild Style emerged as tags that became more complex in design. Making the letters larger and filling in the space in each letter with dots and diagonal and zig-zag lines produced highlyspirited orchestrations of color and form undulating in a rhythmic pattern that made the untrained eye go crazy. The early balloon-shaped exaggerations were called "bubble letters" encouraging a style that became so convoluted that they defy any outsider's attempt to read them. The establishment of a secret code arising out of innovations in content and technique that only informed youth could unscramble demonstrates youth's ability to create a site-specific aesthetic standard. Such a standard receives its vitality from the social relations within which it is created. Several times I sat with Risk-e, Rip, J-Zone, Cruze and their "toys" (recruits) listening to them comparing styles and allocating fame. Lippard (1984) says,

it all begins with that other idealism-the one we are fed in schools-about art being some exalted "gift" to society and artists being alone, superior geniuses, whooping it up in their ivory garrets. However, when students get out, they often find it is hard to give their "gifts" away; some succeed, some get bitter, and some try to demythalize the role of art and to change the system in which it operates. (p. 342)

Insight into the origins of conventions that have historically driven art, as a way of understanding how standards are set and met, might appear frivolous were it not that popular cultural forms such as street art/graffiti have begun to reassert and lay claim to being culturally relevant. Hampson (1979) suggests that in order to make sense of the convolutions 

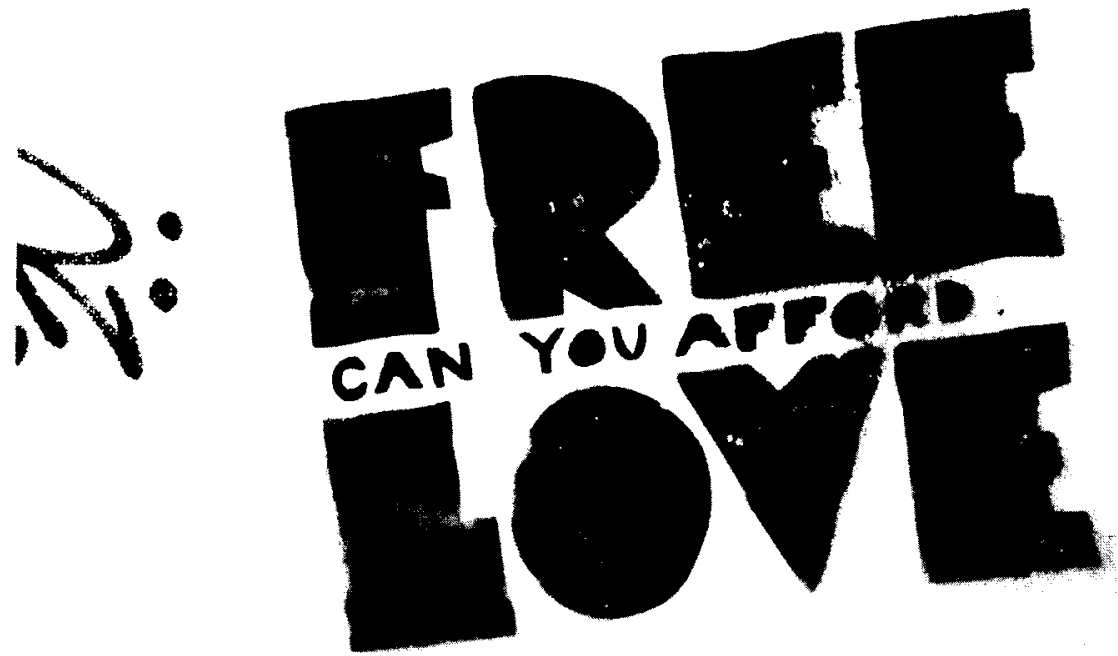

Social comment graffiti.

of the human condition and lay bare conventional influences permeating life, liberties may have to be taken with any chronology of historical events. This seems to be the case with recent criticism of the normalizing influence of tradition on artistic expression under the rubric "modernism" (Foster, 1983, 1984; Gablik, 1984; Habermas, 1983). I will briefly discuss historical precedents put in place by the modernist movement in order to provide a context for understanding street art/graffiti as a reactionary movement.

\section{Modernism and Street Art/Graffiti}

The basic tenets of the modernist tradition first gained momentum during the Enlightenment (Habermas, 1983; Hampson, 1979) by leading the way in the negation of the outworn with a radical transcendence into innovation and difference. The original project of modernity, the fulfillment of the promise of the Enlightenment, was an ambitious effort to develop objective science, universal morality, law, and an autonomous art through an all-pervasive rationality that would free each discipline from the burden of a seeming indeterminacy (Habermas, 1983; Hampson, 1979). Thus all fields of knowledge were parceled into discrete areas of competence taking on an acquired normative structure advancing the adoption of an idealized version of human conduct. Division of human labor into discrete entities inferred the possibility of an idealized model of rational conduct and consequently art as its own topic. A rational framework specific to art centered on constituting standards of acceptability:

It is said to prescribe "specific areas of competence" and to foster, in the artist, a self-critical formalism in which the inherited "code" of the 
medium is manipulated and, in the critic, a historicism that "works" on the new and the different to diminish newness and mitigate difference.

(Foster, 1984, p. 189)

Control of the conditions for doing art enabled institutions of dominant cultural production, museums, universities, galleries (Gablik, 1984) to attempt to secure and legitimate the means and limits of production in art. This control prompted eventual questions, however, about the seeming subordinate role of individualism in an idealized version of human conduct.

Late modernism of the 19 th century and early 20 th century did attempt to rework tradition and overcome accusations of developing false consciousness by underscoring the importance of individual thought processes (Foster 1983, 1984). Rational arguments continued to center on predetermined standards of taste, however, while gratuitously claiming to sanction individualism through an attitude of "art-for-art's-sake." Putting forth an ideal version as if it were the norm meant encouraging and sanctioning a stance through all the various institutions in society, including art, with the expectation that the underlying ideology would become deeply embedded in the individual ethos of the artist and respond as the underlying structure for individual thought. Jameson (1983) is critical of later attempts by modernism to sustain itself by paying lip service to individualism:

Not only is the bourgeois individual subject a thing of the past, it is also a myth; it never really existed in the first place; there have never been autonomous subjects of that type. Rather, this construct is merely a philosophical and cultural mystification which sought to persuade people that they "had" individual subjects and possessed this unique personal identity. (p. 115)

Experts who saw their goal as one of formulating rational structures are at present viewed by postmodern critics as having created, however inadvertently, a gap between themselves and the public-an opposition between their orthodoxy and commonsense practices of everyday life. Modernism continues to come under attack as a self-referencing rationality threatening to organize everyday life into an idealized state wherein an individual's personal biography is at any given time superseded in interaction by a rational plan for action. Such a model, it is argued, continues to be unrecognizable of how diversity is excluded in its formulations. Tucker (1984) says:

Modernism marginalized the issue of artistic motivations or interests outside the art system, denying that art works were themselves bound by a web of connections to specific historical and social contexts. Indeed, in the aesthetic economy of modernism, the amount of pure pleasure provided by a work of art was often gauged by how effectively that work separated itself from the "real" world to provide an imaginary space of ideal reflection. (p. xiii) 


\section{University of Alberta}

Thus the work of the street artists/graffitists has become recognizable as an attempt to reappropriate human expression away from the dominant culture of institutions advancing modernist tradition. Artists such as Risk-e, Rip, J-Zone, and Cruze deliberately explore their own individual action and resultant products as intervening subject matter in the context of what the dominant culture will allow. In so doing personal choices have come to parody deliberately an art world where the script and the parts are purported to have been written already. In the guise of performance art the street artist/graffitist re-presents that which was prior by delving into historical conventions in order to break the bondage controlling how difference is created and sustained. This has not meant a rejection of conventions; rather, the parodying of cultural mechanisms of acceptance and rejection recursively discloses how difference is advanced or thwarted by convention. By delving into historical forms that have been taken for granted and guaranteed in advance of innovation the street artist/graffitist discovers the new within the old.

The street artist/graffitist has departed from traditional views that polarize action as either self-indulgent or enacting a prescribed role. In parodying the taken-for-granted rites of representation they seem to be setting conditions for an active reworking of the ritual of acceptance and rejection. First, doing art in unconventional places establishes the act as a possible criminal offence resulting in a rush of adrenaline and a creative high that comes with working in risk-taking situations. However inadvertently, the site-specific work of the street artist/graffitist draws attention to how human expression is shaped by our view of space-private, public, sociocultural, psychological, physical, spiritual, economic. Second, the possible condemnation of the act as criminal, with a threat of arrest, has come to be seen as a way for graffitists to promote their work while questioning ownership of the freedom and limits of expression; and third, subversive messages in street-smart graphics, utilizing corporate advertising gimmicks, provide free publicity while bringing to question strategies of mass cultural technique such as distribution, accumulation, and consumption.

The delivery system of the street artist/graffitist affirms that newness can be effectively conveyed within the given. It is not the art product that is the exclusive focus of the reworking of the terrain; rather, it is the drama that is played out as commercial galleries invite street artists to come inside or when the street artist/graffitist and the police engage in territorial disputes. Herein lies the realization that the real artistry is in the drama of acceptance and rejection as much as it is in the residue left on the walls. The residue left as a mark on walls merely signals that the play is in progress. Rational modeling of conditions for art, where only certain phenomena get sanctioned has, in the hands of the street artist, drawn us into a drama that stands to rework the terrain on which the meaning of art rests. 
It would seem that differences that fly in the face of what tradition holds to be true, that exhibit opposing tendencies, require an arena in which to be heard and dealt with in reciprocal terms. This suggests we approach conditions favoring association, unification, and containment in the context of inevitable tendencies toward flux, unrest, and resistance. What I speak of here is the veritable presence in any action and interaction of the ground of opposing tendencies continually in a state of creative flux wherein by choice some elements come to exert an influence over what we accept as real. Thus the actualization of a state of difference in any context may be regarded as a healthy form of dialectic and in the larger scheme of things it should not necessarily mean the collapse of order into perpetual chaos.

\section{Note}

1. Unless otherwise referenced, all quotes are from personal interviews with the artists in the last six years.

\section{References}

Acker, K. (1984). Realism for the cause of future revolution. In B. Wallis (Ed.), Art after modernism: Rethinking representation (pp. 31-42). New York: The New Museum of Contemporary Art in Association with Godine.

Foster, H. (1983). Postmodernism: A preface. In H. Foster (Ed.), The anti-aesthetic: Essays on Postmodern culture (IX-3). Washington: Bay Press.

Foster, H. (1984). Re: post. In B. Wallis (Ed.), Art after modernism: Rethinking representation (pp. 189-202). New York: New Museum of Contemporary Art.

Gablik, S. (1984). Has modernism failed? New York: Thames and Hudson.

Habermas, J. (1983). Modernity-an incomplete project. In H. Foster (Ed.), The anti-aesthetic: Essays on postmodern culture (pp. 3-15) Washington: Bay Press.

Hampson, N. (1979). Enlightenment. Markham, ON: Penguin.

Jameson, F. (1983). Postmodernism and consumer society. In H. Foster (Ed.), The anti-aesthetic: Essays on Postmodern culture (p. 111-125). Washington: Bay Press.

Lippard, L. (1984). Trojan horses: Activist art and power. In B. Wallis (Ed.), Art after modernism: Rethinking representation (pp. 31-42). New York: The New Museum of Contemporary Art in Association with Godine.

Toffler, A. (1970). Future shock. Toronto, ON: Bantam.

Tucker, M. (1984). Forward. In Brian Wallis (Ed.) Art after modernism: Rethinking representation (pp. xi-xviii). New York: New Museum of Contemporary Art. 